\title{
Short Communication: Histopathology of red chilli fruit (Capsicum annuum) infected with Colletotrichum acutatum of Java, Indonesia isolates
}

\author{
JUNI SAFITRI MULJOWATI ${ }^{1, \boldsymbol{\nu}}$, LOEKAS SOESANTO ${ }^{2}$, LAURENTIUS HARTANTO NUGROHO ${ }^{3}$ \\ ${ }^{1}$ Faculty of Biology, Universitas Jenderal Soedirman. Jl. Dr. Suparno No. 62, Purwokerto Utara, Banyumas 53122, Central Java, Indonesia. \\ Tel.: +62-281-638794, Fax.: +62-281-631700, `email: juni.muljowati@unsoed.ac.id \\ ${ }^{2}$ Faculty of Agricultural, Universitas Jenderal Soedirman. Jl. Dr. Suparno No. 63, Purwokerto Utara, Banyumas 53122, Central Java, Indonesia \\ ${ }^{3}$ Faculty of Biology, Universitas Gadjah Mada. Jl. Teknika Selatan, Sekip Utara, Sleman 55281, Yogyakarta, Indonesia
}

Manuscript received: 29 November 2020. Revision accepted: 19 January 2021.

\begin{abstract}
Muljowati JS, Soesanto L, Nugroho LH. 2021. Short Communication: Histopathology of red chilli fruit (Capsicum annuum) infected with Colletotrichum acutatum of Java, Indonesia isolates. Biodiversitas 22: 874-880. Colletotrichum acutatum isolates from Malang, Temanggung, Kulonprogo, Brebes, Garut, and Pandeglang in Indonesia varied in their ability to produce pigments. In the present study, the histopathological status of red chilli was investigated during the early phase of infection by $C$. acutatum Java isolate. The results included a description of the histopathological features of red chillies (Capsicum annuum) in the early phase of infection by C. acutatum isolates and the relationship between the origin of the isolates and the time of onset of infection. The red chilli fruits were inoculated with fungal conidia suspension and then the histopathology of chilli fruits was observed at 0 hours (uninfected control), 8 hours, 16 hours, 24 hours, and 32 hours after inoculation. The results showed that $C$. acutatum isolates from Kulonprogo caused host damage within 8 hours, while the other isolates (from Malang, Brebes, Garut and Pandeglang) began to produce similar symptoms at 16 hours or 24 hours. This study revealed for the first time that pathogenic activity begins at the onset of infection, and the resulting anatomical damage to red chillies begins at different times.
\end{abstract}

Keywords: Anatomical structure, Colletotrichum acutatum, Java, pigment, red chilli

\section{INTRODUCTION}

Colletotrichum is a widespread genus of pathogenic fungi that causes anthracnose in host plants (Gautam 2014a,b). In Indonesia, the main causes of anthracnose are C. capsici, C. gloeosporioides, C. nymphaea, and $C$. acutatum (Saxena et al. 2016). Hakim et al. (2014) found that $C$. acutatum commonly causes anthracnose, causing crop losses in the pre-to post-harvest period. Several environmental factors such as air temperature, humidity, and light penetration also play important role in the development of anthracnose disease. Anthracnose on chilli fruits (Capsicum annuum L.) is more severe in humid areas than on dry land (Than et al. 2008)

In Indonesia, red chilli production is concentrated on Java Island, although red chilli cultivation has also begun outside of Java. Red chilli production centers in Java (Malang, Temanggung, Kulonprogo, Brebes, Garut and Pandeglang) have different environmental characteristics. Differences in environmental characteristics as well as the methods of cultivation and pest control, may affect the histopathological effects and virulence of $C$. acutatum isolates (Sharma and Kulshrestha, 2015; Ansari et al. 2018).

Plant cell walls are dynamic structures that allow interactions between plants and pathogens (Underwood 2012; Miedes et al. 2014). For instance, fungal necrotrophs continuously destroy the cell wall of host plant by excreting many degradation enzymes. Host plants have developed defense systems to prevent the development of pathogenic diseases. However, pathogens may still be able to use metabolic products to support their growth and infection (Bellincampi et al. 2014).

In the early phase of infection, Colletotrichum species excretes cutinase to weaken host plant's defenses (Pandey et al. 2012), as well as polygalacturonase and pectate lyase, which function to degrade the pectin polymer and hydrolyze the cuticle. Anand et al. (2008) found that virulent Colletotrichum strains excrete more pectinase than avirulent strains. In addition to producing enzymes, $C$. acutatum also produces and secretes pigments. Based on this pigment production, $C$. acutatum classified into chromogenic (i.e. pigment-producing) $C$. acutatum and non-chromogenic $C$. acutatum (González et al. 2006)

24 hours after exposure to $C$. acutatum, infected red chilli fruits may not show any symptoms of plant diseases. During this asymptomatic phase of infection, the pathogen invades the plant cell without causing lethal damage and is considered hemibiotrophic. In the next phase, the pathogen penetrates the cell wall and continues to grow; in this phase it is classified as a sub-cuticular intracellular fungus, indicating its ability to grow in the cell wall before entering the lumen (Wharton and Schilder 2008).

The $C$. acutatum isolates used in this study were taken from Malang, Temanggung, Kulonprogo, Brebes, Garut, and Pandeglang, which are centers for the production of red 
chilli in Indonesia. In this study, we investigated the ability of $C$. acutatum isolates to produce anthracnose symptoms in the initial phase of infection. Since histopathological status is related to anatomical changes due to $C$. acutatum infection, we explored the histopathological status of red chilli during the early phase of infection by $C$. acutatum. Moreover, we assessed which isolate most rapidly caused lesions on red chilli fruits. The results of this study shed light on the histopathological status of red chilli fruits in early phase of infection by $C$. acutatum isolates, as well as the pathogenic activities of the fungi.

\section{MATERIALS AND METHODS}

\section{Fungus and plant material}

Colletotrichum acutatum isolates were obtained from several regions: Malang, Temanggung, Kulonprogo, Brebes, Garut, and Pandeglang (Figure 1). Each isolate was grown in Potato Dextrose Agar medium and incubated at room temperature for 7 days. A $5 \mathrm{~mm}$ diameter piece of $C$. acutatum colony was taken from each isolate, and a conidia suspension was prepared in sterile distilled water at a concentration of $1 \times 10^{5}$ conidia/mL (Pandey et al. 2012). The TM 999 red chilli cultivar was used as the test plant material, as it is the most common cultivar grown by red chilli farmers in Java. Cultivation of red chillies in the production center of Brebes was carried out in a nonshading monoculture. Application of initial fertilizer uses a dose of $100 \mathrm{Kg} / \mathrm{Ha} \mathrm{Za}, 135 \mathrm{Kg} / \mathrm{Ha} \mathrm{TSP}$, and $100 \mathrm{Kg} / \mathrm{Ha} \mathrm{KCl}$; the second was carried out after the plants are 1 month old

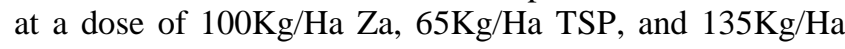
$\mathrm{KCl}$; and the third was done after the plants are 5 months old with a dose of $100 \mathrm{Kg} / \mathrm{Ha} \mathrm{Za}$ and $135 \mathrm{Kg} / \mathrm{Ha} \mathrm{KCl}$. Red chilli fruits from 60-day-old plants were taken from cultivation area in Brebes production center, then carried to the laboratory for the following treatments.

\section{Pathogenicity tests}

Using a sterile needle, a $0.5 \mathrm{~mm}$-hole was made $2 \mathrm{~cm}$ below the red chilli fruits' stalks (Silva et al. 2014). Each hole was inoculated with $10 \mu \mathrm{L}$ Java isolates of $C$. acutatum conidia suspension using a micropipette, except for control one. The inoculated red chillies were placed in an open container, and the inoculated area was covered using a wet cotton mat. Cotton moisture was maintained by spraying sterile distilled water on the cotton when it starts to dry. The chillies were, then, incubated at room temperature around $27^{\circ} \mathrm{C}$ and room humidity around $80 \%$ for 0 hour (non-inoculated control), 8 hours, 16 hours, 24 hours, and 32 hours after inoculation (h.a.i), respectively with 5 replications. Symptoms were recorded at various times of intervals. The treated chillies, especially the parts of the pathogen inoculated area were then used for the preparation of embedded specimens.

\section{Preparation of embedded specimens to examine the effects of pathogen inoculation}

Specimens were prepared for histopathological analysis as previously described by Ajmal et al. (2016). The red chilli fruit tissue specimens used to observe the effect of pathogen inoculation on histological damage were obtained from the above-mentioned experiments, using the embedded specimens that were prepared as follows: Fixation. Red chilli fruits were cut into $1.5-\mathrm{cm}$ pieces, including the inoculation site. Specimens were then fixed in formaldehyde-alcohol-acetic acid for 24 hours. Staining, dehydrating, infiltrating, and embedding. The specimen was cleaned in $70 \%$ alcohol for 24 hours, incubated with safranin (1\% safranin in $70 \%$ alcohol) for 7 hours, and dehydrated in increasing concentrations of alcohol $(70 \%, 80 \%, 96 \%)$ for 10 minutes at each concentration. Alcoholization was carried out using ethanol: xylol (3: 1, 1: 1, 1: 3) solutions, followed by incubation in pure xylol for 30 seconds. Infiltration was carried out in xylol: paraffin solution (1: 9 ratio by volume) for 10 hours, and pure paraffin for 1 hour in an oven.

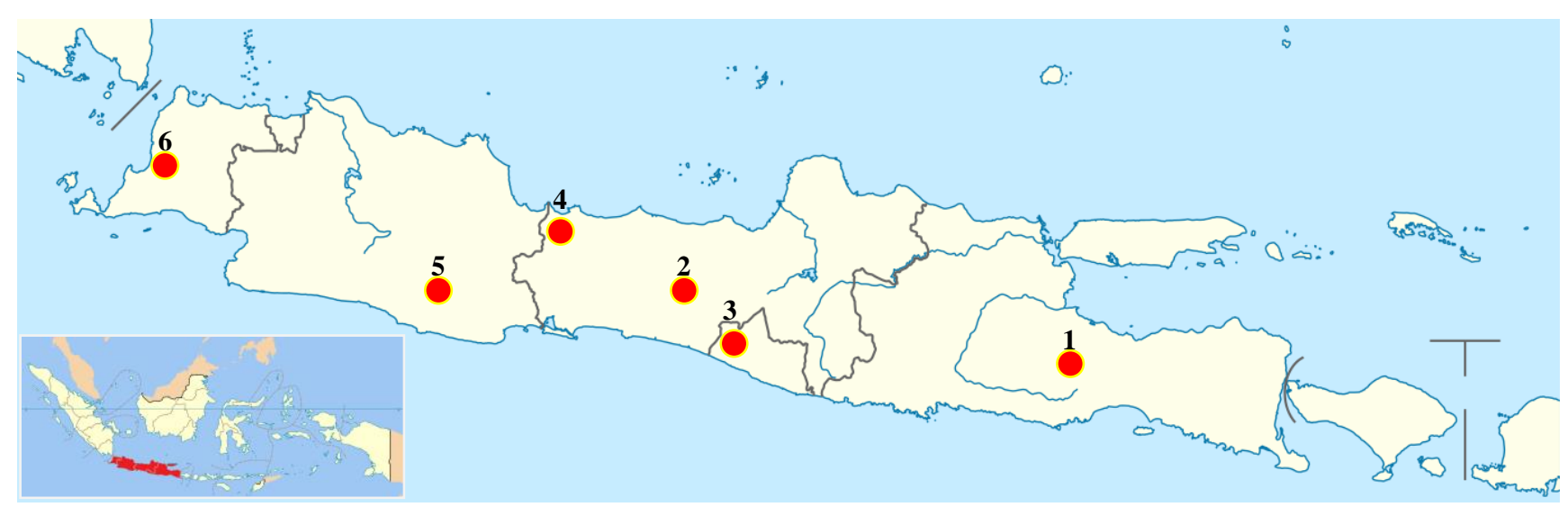

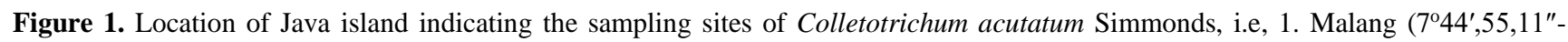

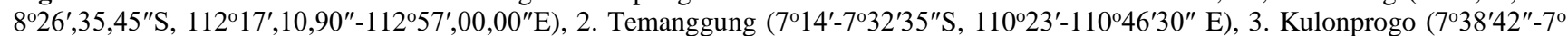

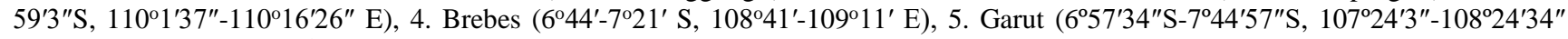
E),6. Pandeglang $\left(6^{\circ} 21^{\prime}-7^{\circ} 10^{\prime} \mathrm{S}, 104^{\circ} 48^{\prime}-106^{\circ} 11^{\prime} \mathrm{E}\right)$ 
Specimens were then left to solidify for 24 hours. Mounting. Sectioning (thickness: $10 \mu \mathrm{m}$ ) was performed by slicing the paraffin block containing the plant organ using a microtome apparatus. The paraffin slices were then placed on microscope slides smeared with glycerin: albumin (1: 1 ), dropped by distilled water, and left in a thermostat for 24 hours. The specimens were mounted using Entellan (Merck). Furthermore, the resulting specimens were observed under light microscopy to observe the effect of pathogenic activity on the histology of red chillies. Observations. Observations of the histopathological status of anthracnose symptoms were performed according to the treatment time. The objects were microtome sliced with a thickness of $10 \mu \mathrm{m}$ and observed using a light microscope at magnifications of $40 \times$ and $100 \times$.

\section{Detection on formation and analysis of pigment compound groups \\ Colletotrichum acutatum isolates from Malang,} Temanggung, Kulonprogo, Brebes, Garut, and Pandeglang were cultured and incubated for seven days on Potato Dextrose Broth. The culture filtrate was harvested through Whatman filter paper no. 41. Afterward, the filtrate was analyzed for compound groups according to (Geetha et al. 2016). The data obtained were whether $C$. acutatum isolates from red pigments or not, and the group of compounds formed.

\section{Data analysis}

The observational data were analyzed descriptively.

\section{RESULTS AND DISCUSSION}

\section{Histology of uninfected (control) red chilli fruit}

The observation using light microscope of control red chillies showed a compact structure (Figure 2). Histologically, the epicarpium layer which consists of a single layer of epidermal cells appeared compact. The cuticle layer protects/covers the outer cell wall of the epidermis. The mesocarpium tissue, which consists of two layers of collenchyma tissue, was found to be compact. In the deeper layer, there is a vein bundle containing xylem and phloem. The intercellular space cell appears to have clear boundaries. Giant cell was found in the mesocarpium layer with a compact cell wall. Furthermore, the endocarpium layer also looks compact, composed of single-layer cells.

\section{Symptoms produced by Colletotrichum acutatum isolates on red chilli fruit}

The anthracnose symptoms due to $C$. acutatum isolate of Kulonprogo appeared at 8 h.a.i. (Figures 3.A, 4.A, 5.A, and 6.A), while the isolates of Malang, Brebes, Garut, and Pandeglang showed symptoms at 16 h.a.i., and the isolate from Temanggung exhibited symptoms at 24 h.a.i. The biotrophic phase occurs over a period of between 12-24 hours. Furthermore, at 24 hours after inoculation, it begins and marked by the appearance of symptoms. The initial symptom was brown spots which gradually turned dark color. Morphologically, anthracnose symptoms begin in the inoculated area on red chilies. In the early phase of infection, the fruit did not show brown color. The timing of the appearance of anthracnose symptoms differs among $C$. acutatum isolates from different locations, which may be related to differences in their ability to produce pigments. C. acutatum isolates from Malang, Kulonprogo, Brebes, Garut and Pandeglang were able to produce pigments, which may be related to inducing anthracnose symptoms. In addition, the amount of pigment produced was considered to be related to the severity of the disease. C. acutatum Java isolates from Temanggung did not produce pigments, while $C$. acutatum Java isolates from Kulonprogo produced more pigment than other regions (Table 1).

Table 1. Production and color of the Colletotrichum acutatum Java, Indonesia isolates in Potato Dextrose Broth

\begin{tabular}{lcl}
\hline $\begin{array}{c}\text { Collection sites of Colletotrichum } \\
\text { acutatum } \text { isolates }\end{array}$ & $\begin{array}{c}\text { Pigment } \\
\text { production }\end{array}$ & $\begin{array}{c}\text { Pigment } \\
\text { color }\end{array}$ \\
\hline Malang & + & Red \\
Temanggung & - & - \\
Kulonprogo & + & Dark red \\
Brebes & + & Red \\
Garut & + & Red \\
Pandeglang & + & Red \\
\hline
\end{tabular}

Note: -: does not produce pigment; +: produce pigment

Table 2. Detection of compound groups in pigments produced by Colletotrichum acutatum isolates

\begin{tabular}{lcccccc}
\hline \multirow{2}{*}{ Test } & \multicolumn{7}{c}{ The origin of Colletotrichum acutatum } \\
\cline { 2 - 7 } & $\mathbf{1}$ & $\mathbf{2}$ & $\mathbf{3}$ & $\mathbf{4}$ & $\mathbf{5}$ & $\mathbf{6}$ \\
\hline Alkaloids & - & - & - & - & - & - \\
Coumarin & - & - & - & - & - & - \\
Flavonoids & - & - & - & - & - & - \\
Phenol & - & - & - & - & - & - \\
Quinone & - & - & - & - & - & - \\
Saponins & - & - & - & - & - & - \\
Steroids & - & - & + & - & - & - \\
Tannins & + & - & ++ & + & + & + \\
Terpenoids & - & - & - & - & - & - \\
Benzoin & - & - & + & - & - & - \\
\hline Note:
\end{tabular}

Note: 1. Malang; 2. Temanggung; 3. Kulonprogo; 4. Brebes; 5.

Garut; 6. Pandeglang;-: none; +: produce; ++: highly produce

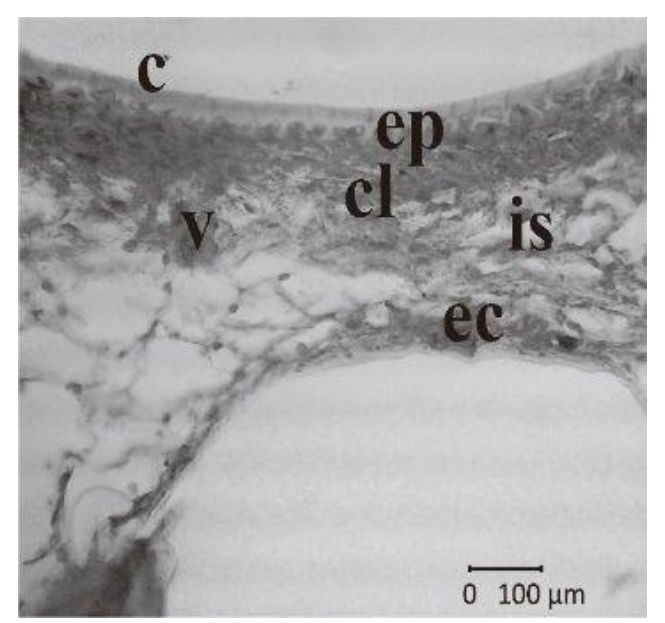

Figure 2. Anatomical structure of uninfected (control) red chilli fruit in cross-section. c: cuticles, ep: epicarpium, cl: collenchyma, v: phloem/xylem, is: intercellular space cell, ec: endocarpium 


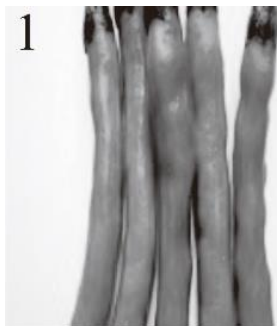

2
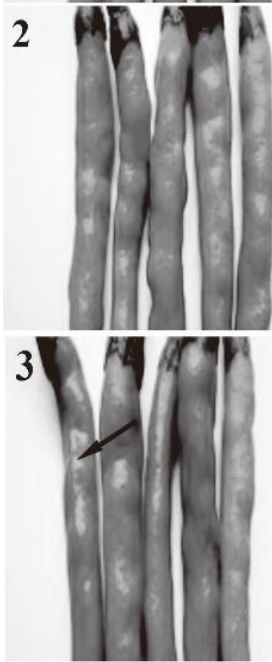

A
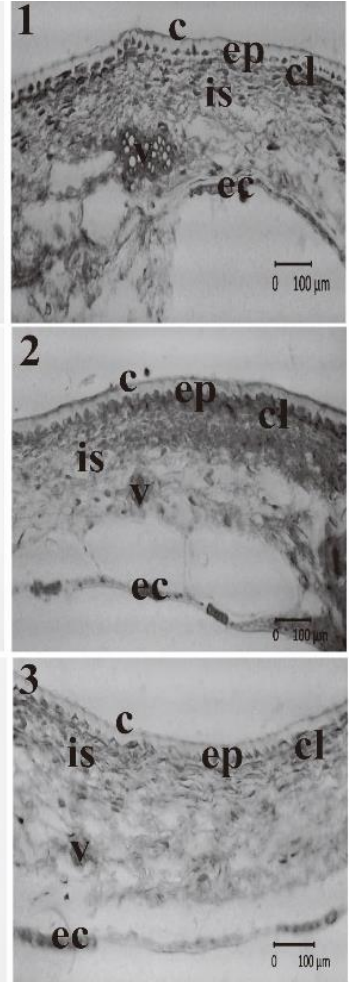

B
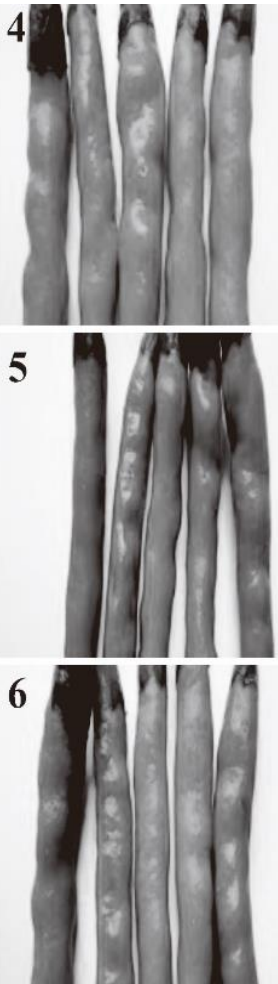
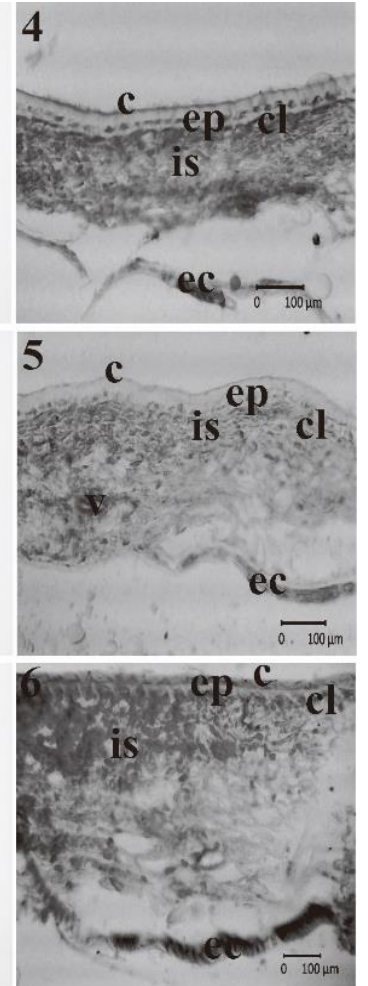

B

Figure 3. Inoculated red chilli fruit (A) and (B) anatomical structures 8 hours after inoculation by Colletotrichum acutatum isolates. The Colletotrichum acutatum isolates were from 1. Malang, 2. Temanggung, 3. Kulonprogo, 4. Brebes, 5. Garut and 6. Pandeglang. The arrows point to the anthracnose symptoms. c: cuticles, ep: epicarpium, cl: collenchyma, $v$ : phloem/xylem, is: intercellular space cell, ec: endocarpium

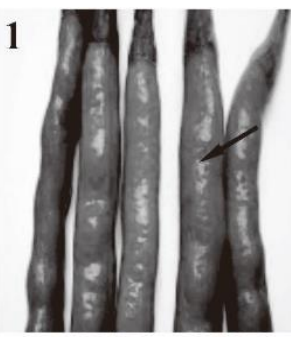

2

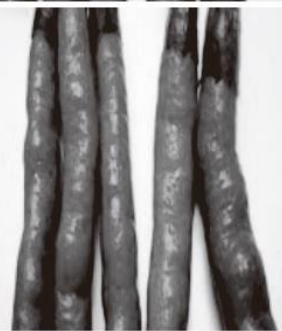

3

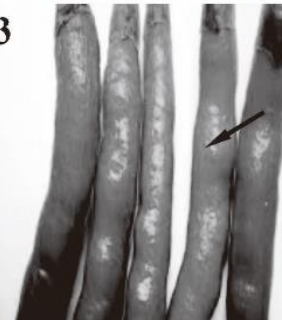

A
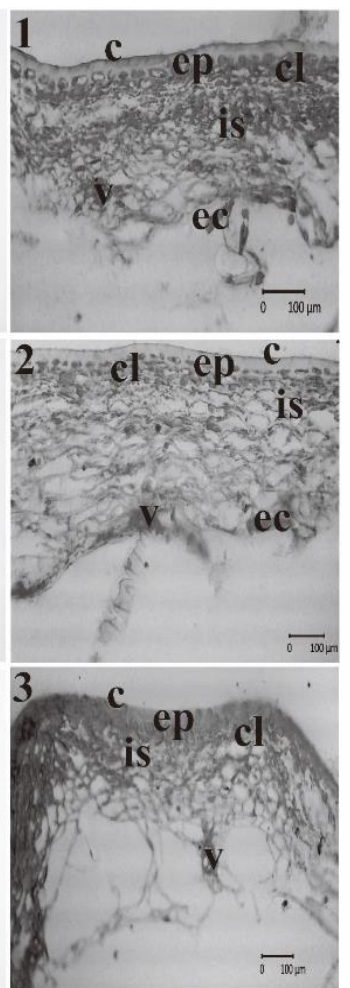

B
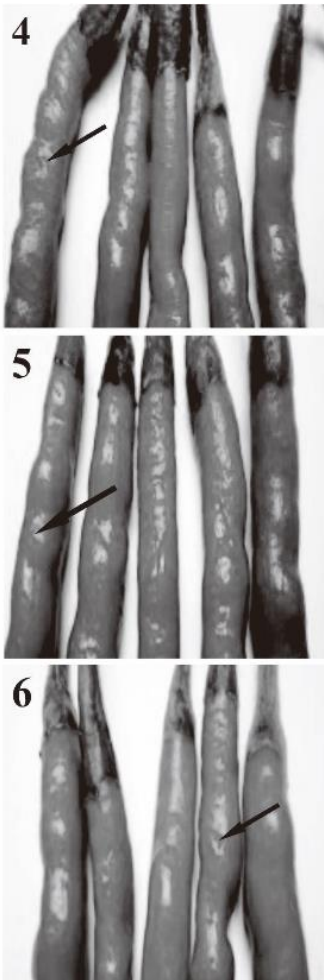

A
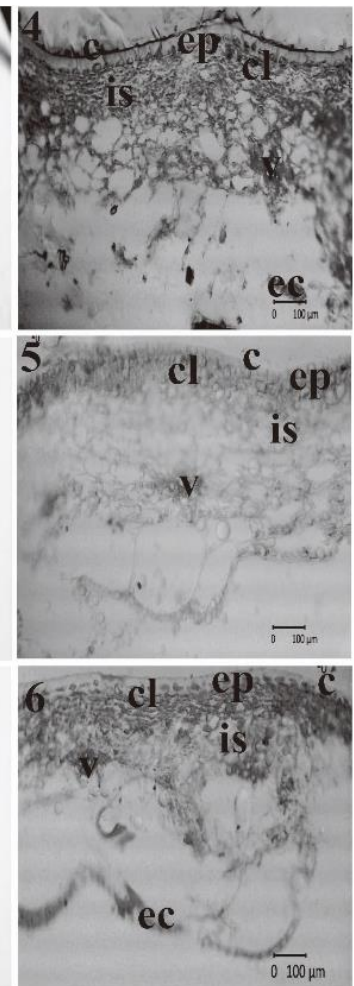

B

Figure 4. Inoculated red chilli fruit (A) and (B) anatomical structures 16 hours after inoculation by Colletotrichum acutatum isolates. The Colletotrichum acutatum isolates were from 1. Malang, 2. Temanggung, 3. Kulonprogo, 4. Brebes, 5. Garut and 6. Pandeglang. The arrows point to the anthracnose symptoms. c: cuticles, ep: epicarpium, cl: collenchyma, v: phloem/xylem, is: intercellular space cell, ec: endocarpium 

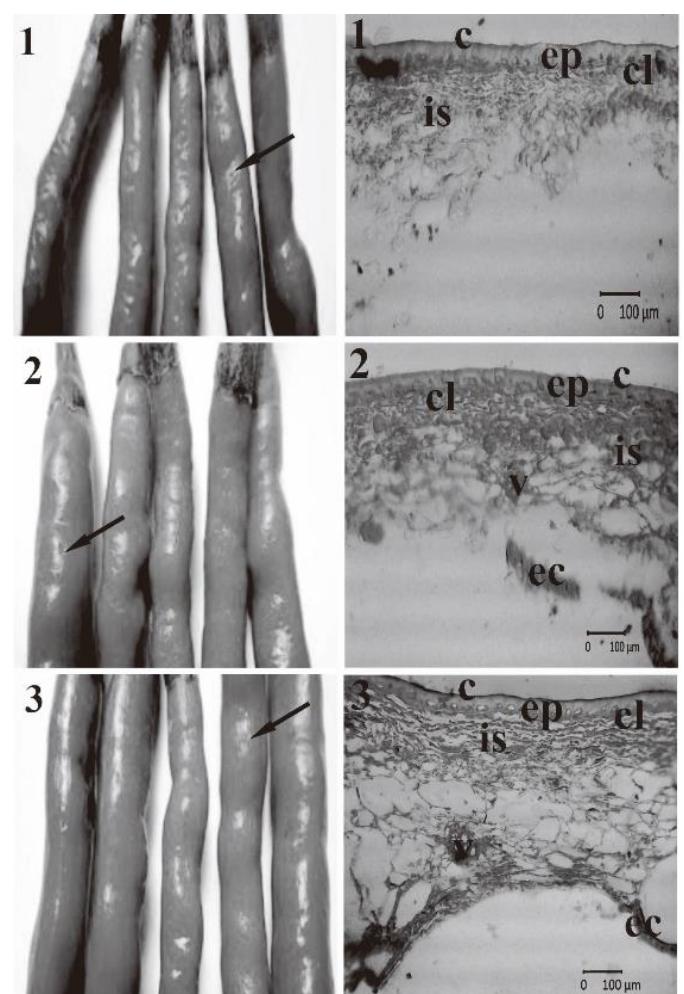

A
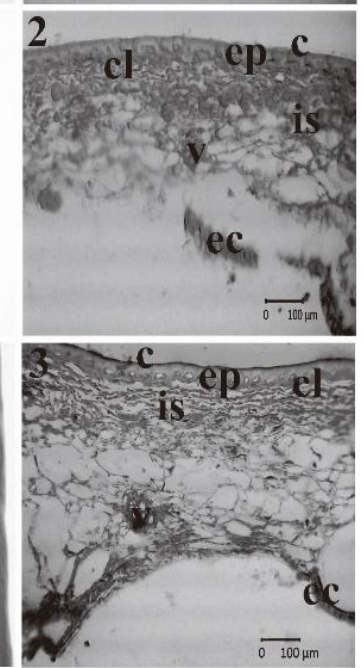

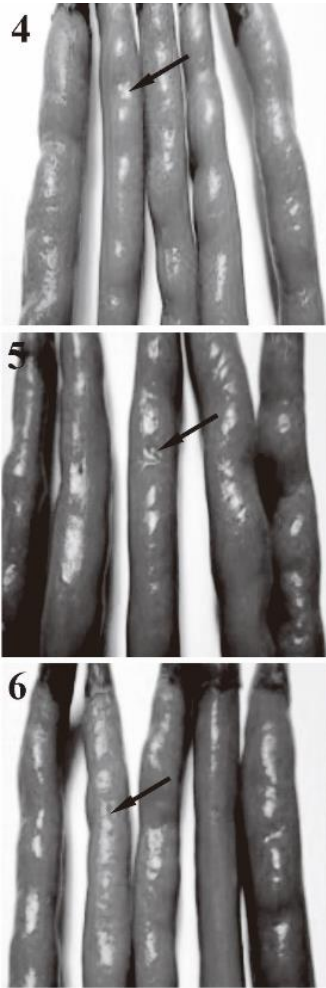

A
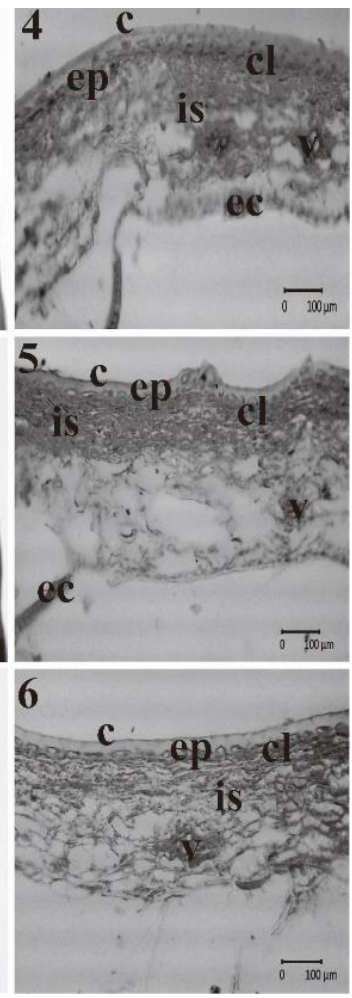

B

Figure 5. Inoculated red chilli fruit (A) and (B) anatomical structures 24 hours after inoculation by Colletotrichum acutatum isolates. The Colletotrichum acutatum isolates were from 1. Malang, 2. Temanggung, 3. Kulonprogo, 4. Brebes, 5. Garut and 6. Pandeglang. The arrows point to the anthracnose symptoms. c: cuticles, ep: epicarpium, cl: collenchyma, v: phloem/xylem, is: intercellular space cell, ec: endocarpium.
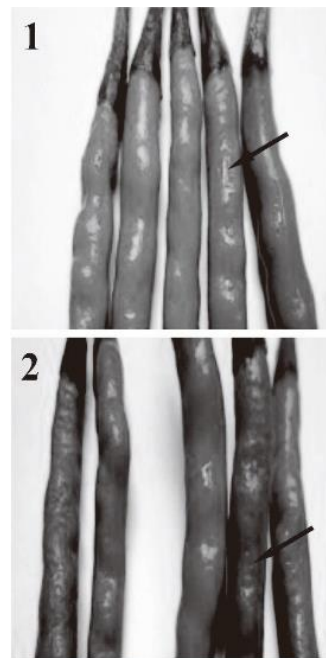

3

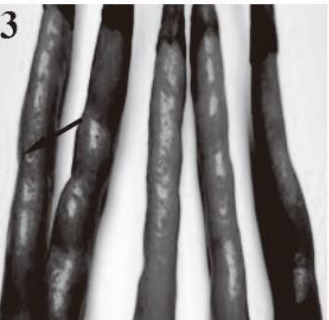

A
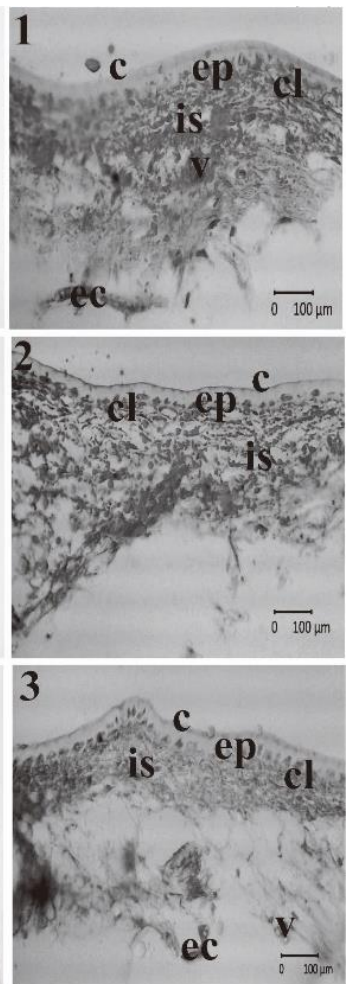

B

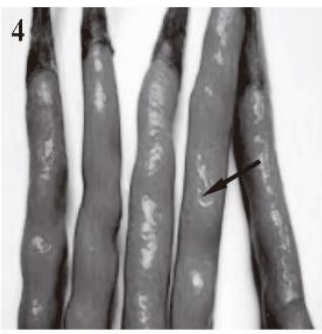

5

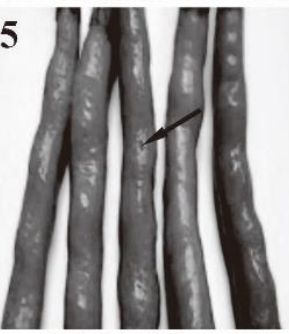

6

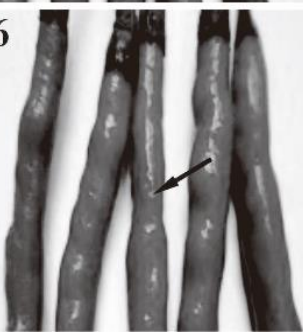

A
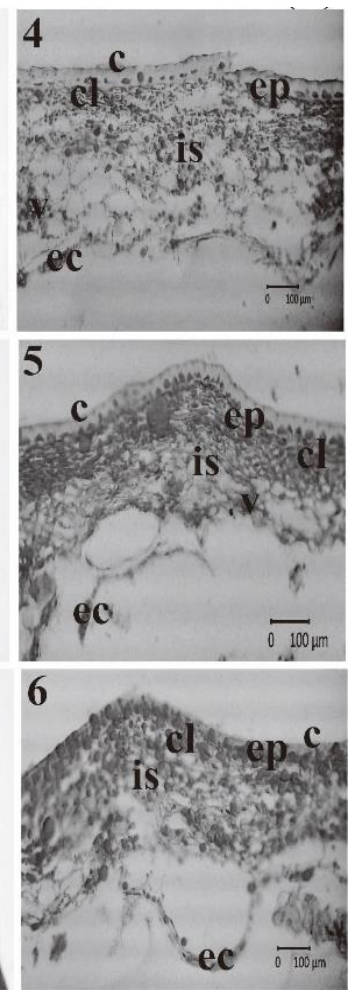

B

Figure 6. Inoculated red chilli fruit (A) and (B) anatomical structures 32 hours after inoculation by Colletotrichum acutatum isolates. The Colletotrichum acutatum isolates were from 1. Malang, 2. Temanggung, 3. Kulonprogo, 4. Brebes, 5. Garut and 6. Pandeglang. The arrows point to the anthracnose symptoms. c: cuticles, ep: epicarpium, cl: collenchyma, v: phloem/xylem, is: intercellular space cell, ec: endocarpium 


\section{Histopathology of red chilli fruit infected with Colletotrichum acutatum isolates}

Based on observations using light microscope, the anatomical structure of red chillies at the incubation period of 8 h.a.i. (Figure 3.B), found relatively same when compared to control fruits (Figure 2). But the fruits inoculated with $C$. acutatum from Kulonprogo showed more tenuous than other treatments. At the incubation period of 16 h.a.i. (Figure 4.B), the cells that make up the red chilli fruit tissue inoculated with $C$. acutatum from Malang, Brebes, Garut, and Pandeglang showed more tenuous than the control. In the incubation period of 24 h.a.i. (Figure 5.B red chilli fruit tissue also appeared more tenuous than the control. Meanwhile, inoculation of $C$. acutatum from Malang, Brebes, Garut, and Pandeglang resulted in more tenuous tissue than those inoculated by $C$. acutatum from Temanggung. At the incubation period of 32 h.a.i (Figure 6.B), the anatomical structure of the red chilli fruits looks more tenuous and even appears that the tissue structure has separated.

Histopathological observations (Figures 3.B, 4..B, 5.B and 6.B) revealed tissue damage in red chilli fruits inoculated with $C$. acutatum Java isolate from Kulonprogo at 8 h.a.i. This showed that pathogenic activity had begun in the initial phase of infection, even though melanization associated with anthracnose symptoms was not observed. Red chilli tissue damage caused by $C$. acutatum isolates from Malang, Brebes, Garut, and Pandeglang began to appear at 16 h.a.i., while damage by $C$. acutatum isolates of Temanggung began at 24 h.a.i.

\section{The compound groups in pigments produced by Colletotrichum acutatum isolates}

Detection of pigments compound groups produced by C. acutatum Java isolates indicated that the isolates from Malang, Kulonprogo, Brebes, Garut, and Pandeglang produced tannins, while the other isolates did not produce (Table 2). Tannins produced by Kulonprogo isolates had a stronger pigment color (dark red) than those produced by the isolates from other regions (Table 1).

\section{Discussion}

Histology of uninfected red chilli fruit showed a compact structure. The epicarpium, mesocarpium, and endocarpium consist of layer of cells appeared compact. This result is very similar to that previously reported by Weryszko-Chmielewska and Zenia (2012).

In the early phase of infection, plant pathogens produce the pectinase enzyme which plays a role in pathogenesis (Yakoby et al. 2000). Pectinase degrades the pectin compounds that make up the middle lamella, resulting in the separation of cells making up the parenchymal tissue and increasing the space between cells. C. acutatum Java isolates can produce pectinase enzyme (Muljowati et al. 2020), which degrades plant cell walls.

The anthracnose symptoms due to $C$. acutatum Java isolates showed at different times. C. acutatum isolates from Kulonprogo caused host damage within 8 hours, while the other isolates (from Malang, Brebes, Garut and
Pandeglang) began to produce similar symptoms at 16 hours or 24 hours. This result is not in line with the observation uncovered by Arroyo et al. (2009), that $C$. acutatum conidia germination occurred starting at 4 hours after inoculation. Furthermore, at 24 hours after inoculation, it begins, which is marked by the appearance of symptoms. The initial symptoms are brown spots, and over time the spot darkens. The timing of the appearance of brown color at the anthracnose symptoms different among C. acutatum isolates from different locations. According to Elsenman and Casadevall (2012), melanin is a pigment with a granular structure, and is a product of the polymerization of phenol compounds. The function of melanin is to protect fungi from environmental influences. It also plays a role in pathogenesis and the invasion of host tissue.

Besides producing the pectinase enzyme, $C$. acutatum isolates from Malang, Kulonprogo, Brebes, Garut and Pandeglang were able to produce red pigment in culture medium, while isolates from Temanggung did not produce pigments. Pigments produced by $C$. acutatum isolates are tannins compound group (Geetha et al. 2016). Higher tannin concentrations result in stronger pigment color (dark red). Tannin acyl-hydrolase commonly referred to as tannase, hydrolyses the ester bonds of hydrolyzable tannins, gallotannins, ellagitannins to produce gallic acid, glucose and galloil ester (Govindarajan et al. 2016). Belmares et al. (2004) stated that plants and microbes can produce tannases. Tannase plays a role in the ability of pathogens to cause symptoms of plant diseases (Sharma, 2019). Therefore, the pectinase and tannase enzymes in the red pigment produced by the Java isolate $C$. acutatum also play a role in causing symptoms of anthracnose disease in red chilies. In all incubation periods, anthracnose symptoms and tissue damage occurred more rapidly in red chillies inoculated with $C$. acutatum isolate from Kulonprogo, while inoculations of $C$. acutatum isolate from Temanggung resulted in the slowest anthracnose symptoms and tissue damage

Anthracnose symptoms and tissue damage in red chillies inoculated with $C$. acutatum have been seen in the early stages of infection. This indicates that pathogenic activity has started at initial phases.

It remains unclear why the pigment concentration produced by $C$. acutatum Java isolates was not the same. Therefore, it has been suggested that the factors affect the ability of $C$. acutatum isolates to produc pigments should be investigated.

\section{ACKNOWLEDGEMENTS}

The authors would like to express their gratitude to the Research and Community Service Directorate: Directorate General of Research and Development, Ministry of Research, Technology, and Higher Education, which allowed the authors to conduct this research under Doctoral Dissertation Scheme Number 10984/UN23.14/PN/2017. The authors would also like to thank the Head of 
Mycology, Plant Structure, and Development Laboratories of the Faculty of Biology at Jenderal Soedirman University, Purwokerto, Indonesia, for their technical support in this research.

\section{REFERENCES}

Ajmal M, Abida A, Anum A, Shaista A, Brian GN. 2016. Stem histopathology of sesame seedlings infected with Alternaria alternata. Microsc Res 4: 11-19.

Anand T, Ramanujam B, Thiruvengadam R, Gandhi K, Manikam R, Govindasamy S. 2008. Production of cell wall degrading enzymes and toxins by Colletotrichum capsici and Alternaria alternata causing fruit rot of chillies. J Plant Prot Res 48: 437-451.

Ansari A, Khanzada MA, Rajput MA, Sultan Maitlo1, Rajput AQ, Ujjan A. 2018. Effect of different abiotic factors on the growth and sporulation of Colletotrichum gloeosporioides causing anthracnose of mango. Plant Protection 02 (01): 23-30.

Arroyo FT, Javier M, Gregorio G, Berta DS, Carmen B, Maria P, Cesar B, Fernando R. 2005. Ultrastructure of the early stages of Colletotrichum acutatum infection of strawberry tissue. Can J Bot 83: 491-500.

Bellincampi D, Felice C, Vincenzo L. 2014. Plant cell wall dynamics and wall-related susceptibility in planta-pathogen interactions. Front Plant Sci 5: $1-9$.

Belmares R, Contreras-Esquivel JC, Rodriguez-Hererra R, Coronel AR, Aquilar CN. 2004. Microbial production of tannase: an enzyme with potential use in food industry. Lebensm-wiss u- Technol 37: 857-864.

Elsenman HC, Arturo C. 2012. Synthesis and assembly of fungal melanin. Appl Microbiol Biotechnol 93: 931-40.

Gautam AK. 2014a. Colletotrichum gloeosporioides: biology, pathogenicity and management in India. Plant Physiol Pathol 2: 2 DOI: $10.4172 / 2329-955 X .1000125$

Gautam AK. 2014b. The Genera Colletotrichum: An incitant of numerous new plant diseases in India. J New Biol Rep 3: 9-21.

Geetha S, Kokkaiah I, Sinthia G, Palanichamy M. 2016. Preliminary phytochemical screening of different solvent extracts and stem of Crataeva religiosa Hook Frost. Intl J Curr Microbiol Appl Sci 5: 116122.

González E, Turner BS, James CC. 2006. Clarification of the etiology of Glomerella leaf spot and bitter rot of apple caused by Colletotrichum spp. based on morphology and genetic, molecular, and pathogenicity tests. Phytopathology 96 (9): 982-992.
Govindarajan RK, Reevathi S, Rameshkumar N, Khrisnan M, Kayalvizhi N. 2016. Microbial tannase: current perspectives and biotechnological advances. Biocatalys Agric Biotechnol 6: 168-175.

Hakim A, Muhamad S, Widodo. 2014. Ketahanan penyakit antraknosa terhadap cabai lokal dan cabai introduksi. Bul Agrohorti 2 (1): 31-36. [Indonesian]

Liu GY, Victor N. 2009. Color me bad: microbial pigments as virulence factors. Trends Microbiol 17: 406-413.

Miedes E, Vanholme R, Boerjan W, Molina A. 2014. The role of the secondary cell wall in plant resistance to pathogens. Front Plant Sci 5 (e1001123): 358. DOI: 10.3389/fpls.2014.00358.

Muljowati JS, Soesanto L, Nugroho LH. 2020. Production of pectinase enzymes by Colletotrichum acutatum Simmonds causing anthracnose in red chilli ( Capsicum annuum, L). IOP Conf Ser Earth Environ Sci 593 (1): 012036. DOI: 10.1088/1755-1315/593/1/012036.

Pandey A, Pandey BK, Muthukumar M, Yadava LP, Chauhan UK. 2012. Histopathological study of infection process of Colletotrichum gloeosporioides Prnz and Sacc. on Mangifera indica L. Plant Pathol J 11: $18-24$.

Saxena A, Richa R, Vijai KG, Harikesh BS. 2016. Chilli anthracnose: the epidemiology and management. Front Microbiol 7: 1-18

Sharma KP. 2019. Tannin degradation by phytopathogen's tannase: A plant's defense perspective. Biocatalys Agric Biotechnol 21: 101342. DOI: $10.1016 /$ j.bcab.2019.101342.

Sharma M, Kulshrestha S. 2015. Colletotrichum gloeosporioides: An anthracnose causing pathogen of fruits and vegetables. Biosci Biotechnol Res Asia 12 (2): 1233-1246. DOI: 10.13005/bbra/1776.

Silva SAM, Rosana R, Leandro SAGs, Cláudia PS, Cíntia SB, Margarida GFC, Artur MM. 2014. Resistance in Capsicum spp. to anthracnose affected by different stages of fruit development during pre-and postharvest. Trop Plant Pathol 39: 335-341.

Than PP, Jeewon R, Hyde KD, Pongsupasamit S, Mongkolporn O, Taylor PWJ. 2008. Characterization and pathogenicity of Colletotrichum species associated with anthracnose on chilli (Capsicum spp.) in Thailand. Plant Pathol 57: 562-572.

Underwood W. 2012. The plant cell wall: A dynamic barrier against pathogen invasion. Front Plant Sci 3 (85): 85. DOI: 10.3389/fpls.2012.00085.

Weryszko-Chmielewska E, Zenia M. 2012. Anatomical traits of sweet pepper (Capsicum annuum L.) fruit. Acta Agrobot 64: 181-188.

Wharton PS, Schilder AC. 2008. Novel infection strategies of Colletotrichum acutatum on ripe blueberry fruit. Plant Pathol 57: 122134.

Yakoby N, Stanley F, Amos D, Noel TK, Dov P. 2000. Expression of pectate lyase from Colletotrichum gloeosporioides in C. magna promotes pathogenicity. Mol Plant-Microb Interact 13: 887-891. 